\title{
A nova grande promessa da inovação em fármacos: RNA interferência saindo do laboratório para a clínica
}

\author{
CARLOS FREDERICO MARTINS MENCK
}

\section{Introdução}

A MOLÉCULA de RNA foi recentemente identificada como um possível fármaco capaz de revolucionar a forma com que realizamos terapias de um elevado número de doenças humanas. As atividades biológicas dessas moléculas, empregadas normalmente na forma de dupla fita, foram descobertas na década de 1990 graças à identificação dos mecanismos de interferência do RNA e baseiam-se na capacidade de essas moléculas reduzirem (interferirem) a expressão de determinados genes-alvo. O potencial terapêutico do RNA dupla fita é enorme, sobretudo em processos genéticos que requerem inibição de produtos de genes. Entre as doenças-alvo, destacam-se as terapias tumoral e de agentes infecciosos, especialmente vírus, mas várias outras doenças humanas também poderão ser controladas pela ação dessas moléculas. $\mathrm{O}$ tamanho relativamente grande das moléculas de RNA, sobretudo em comparação com algumas drogas químicas, pode representar um dos problemas a serem enfrentados pelas pesquisas no tema, porém chama a atenção a facilidade com que essas moléculas podem ser projetadas, dependendo apenas da sequência das bases do gene-alvo. Vários protocolos clínicos têm sido testados em humanos nos últimos anos, e os resultados são promissores. É possível que em breve esse tipo de fármaco seja encontrado em farmácias: vale a pena saber o porquê!

\section{O RNA não é só um mero mensageiro do DNA}

Na década de 1980, a comunidade científica se espantou com a revelação de que a molécula de RNA tem atividade catalítica, como as enzimas. Assim, essas moléculas foram chamadas de ribozimas e demonstraram que o RNA pode desempenhar funções que superam em muito a de simples mensageiro para síntese de proteínas. Mas isso foi só o começo. Na década de 1990, resultados com plantas transgênicas começaram a gerar dados completamente inesperados: plantas que superexpressavam genes para produção de pigmentos (e que, portanto, deveriam gerar flores com mais pigmentos, ou seja, com coloração violeta-escuro) apresentaram flores brancas, em razão da ausência de síntese do 
pigmento! No caso, houve o inesperado silenciamento do transgene e do gene endógeno das células dessas flores.

O mecanismo molecular que levava ao silenciamento gênico permaneceu desconhecido por alguns anos, até que, trabalhando com o verme nematoide Caenorbabditis elegans, os grupos dos pesquisadores americanos Andrew Z. Fire e Craig C. Mello descobriram que moléculas de RNA dupla fita (RNAdf) poderiam silenciar a expressão de genes (Fire et al., 1998). Os experimentos realizados para essa descoberta são extremamente simples: ao analisarem o efeito de silenciamento gênico de moléculas de RNA simples fita antissenso e também senso (em relação ao sentido da molécula do RNA mensageiro do gene-alvo), os pesquisadores descobriram que o uso da molécula dupla fita tinha um efeito cem vezes maior. Pela capacidade do RNAdf de interferir na expressão genética, o mecanismo começou a ser chamado de RNA interferência ou simplesmente RNAi.

\section{O mecanismo de RNA interferência funciona em células humanas}

Esse mecanismo de silenciamento foi demonstrado inicialmente em vermes, plantas e insetos, mas demorou três anos para ter sua existência demonstrada em células humanas (Elbashir et al., 2001). Esses experimentos indicaram a importância evolutiva dos mecanismos de RNAi em eucariontes em geral e acenderam ideias do uso potencial tecnológico para moléculas de RNAdf como base para silenciamento gênico com fins terapêuticos em humanos. Além disso, houve a identificação de pequenas moléculas de RNAdf (na forma de grampos) sintetizadas pelas próprias células, a partir do seu genoma cuja função é controlar a expressão de genes celulares. Esses RNA endógenos ficaram conhecidos como microRNA (miRNA) e demonstram que as funções do RNA na célula vão muito além da simples mensagem. Pela descoberta, os doutores Fire e Mello receberam o Prêmio Nobel de Medicina em 2006.

\section{Como funciona a RNA interferência na célula}

Os mecanismos de RNA interferência já são bem conhecidos. Basicamente, genes endógenos são transcritos como um RNAm longo contendo vários miRNA agrupados. Esses miRNA primários são conhecidos como pri-miRNA e contêm sequências de bases palindrômicas, de modo que o emparelhamento entre elas gera estruturas de RNAdf na forma de grampo. Essas moléculas são processadas ainda no núcleo da célula, sendo clivadas por RNAse (Drosha), formando estruturas com cerca de 70 bases, conhecidas como pré-microRNA (pré-miRNA). Essas moléculas são exportadas ao citoplasma (pela enzima Exportina-5) e são novamente processadas por uma RNAse, Dicer, que produz os miRNA maduros que são duplexes de 19 a 23 pares de base. O complexo Risc (do inglês $R N A$ induced silecing complex) é a plataforma proteica que se associa aos miRNA e promove a interação de uma das fitas do RNAdf (RNA-guia) com moléculas de RNA mensageiros. Essa interação ocorre por complementaridade na sequência 
do RNA-guia e do RNAm, e normalmente ocorre na região 3' não traduzida (3' UTR), resultando no silenciamento do RNAm-alvo, seja por degradação desse, seja pelo bloqueio da tradução em proteínas. No caso de bloqueio de tradução, a complementaridade não necessita ser completa, o que indica que um único miRNA pode regular centenas de genes, e cada gene-alvo pode ser regulado por múltiplos miRNA, demonstrando a complexidade dessa rede de regulação gênica. A Figura 1 apresenta um esquema que descreve de forma simplificada como funciona o mecanismo de RNA interferência (para uma revisão, ver Liu, 2008).
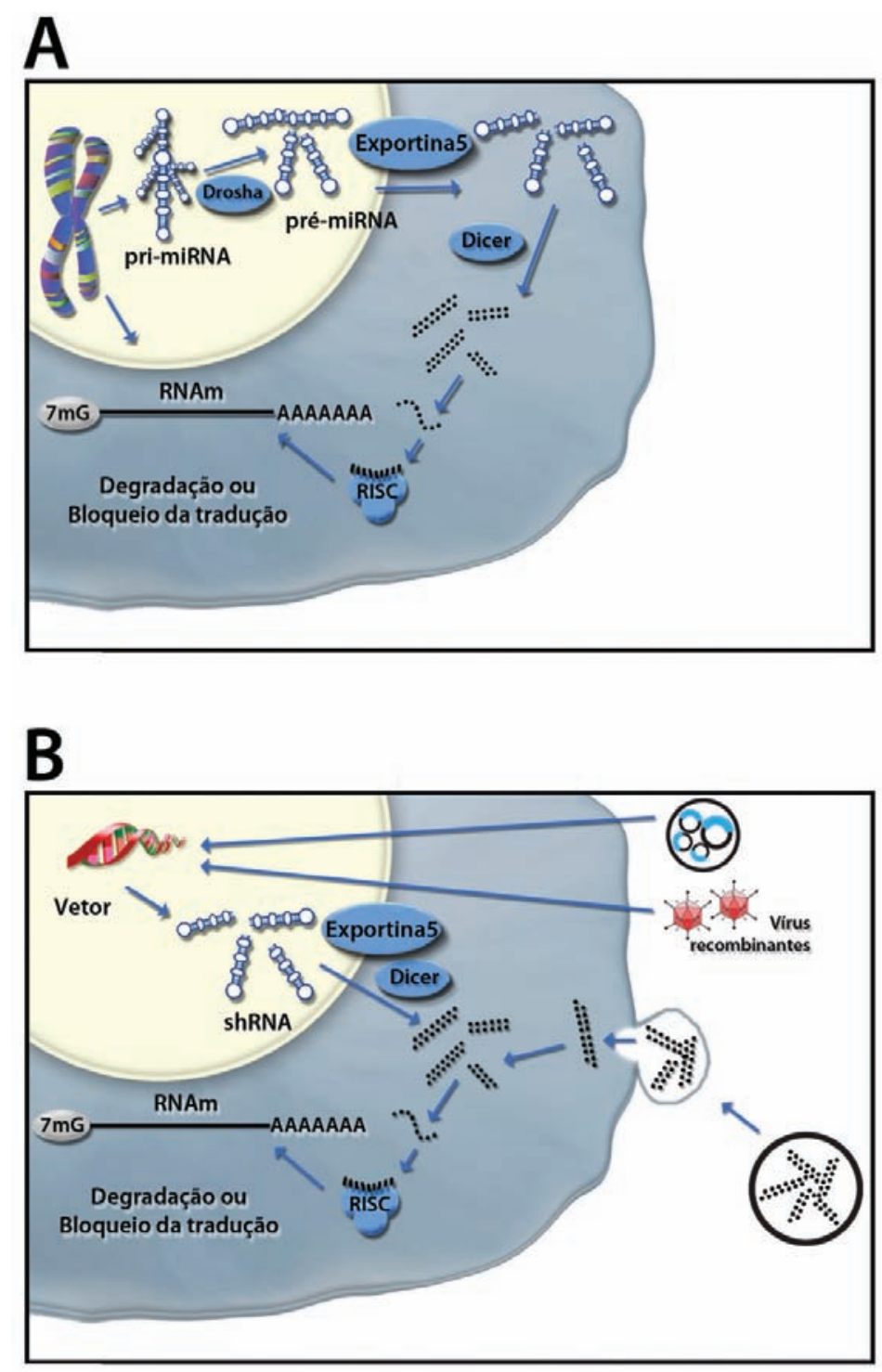

Figura 1 - Ação de RNA interferência em células animais. A) Esquema do mecanismo de RNA interferência, indicando as principais proteínas/complexos proteicos envolvidos; B) esquema mostrando como podemos empregar esses mecanismos para provocar silenciamento de genes de forma dirigida, com duplexes de RNA (siRNA), ou vetores virais ou não para expressão de shRNA. 
A descoberta do processo de regulação gênica através de RNA interferência revolucionou também a forma como se estuda o papel de genes específicos na biologia. O uso de moléculas de RNAdf exógenas como ferramenta pode reduzir a expressão de genes específicos (efeito conhecido como knock-down), de forma que as alterações causadas por essa estratégia possibilitam avaliar quais funções esse gene desempenha na célula. Nesses experimentos, a sequência da molécula de RNAdf é definida pelo pesquisador para interferir no seu genealvo preferido. Essa estratégia também pode ser usada diretamente in vivo (em animais ou mesmo em humanos), e daí a possibilidade de desenvolvimento de fármacos (Tiemann \& Rossi, 2009).

Basicamente, duas abordagens distintas podem ser usadas. Na primeira, vetores genéticos, em geral derivados de vírus (como adenovírus, retrovírus ou vírus adenoassociados), são transduzidos nas células, de modo a expressar genes que são transcritos em moléculas de RNAdf na forma de grampo (similares aos miRNA). Essas moléculas são conhecidas como shRNA (do inglês short hairpin $R N A$ ) e têm como alvo o gene que se deseja silenciar. O shRNA é clivado pela proteína Drosha e assim é processado pela maquinaria de RNA interferência celular. Apesar de esse tipo de abordagem requerer a produção de vetores virais, o que não é um processo simples do ponto de vista de produção de fármacos, ainda assim, como veremos adiante, há algumas estratégias terapêuticas que estão sendo testadas, como protocolos clínicos em humanos, empregando vetores que expressam shRNA.

Em uma segunda abordagem, pequenas moléculas de RNAdf podem ser introduzidas diretamente nas células em cultura, visando à degradação específica do gene-alvo. Essas moléculas são conhecidas como siRNA (small interfering $R N A$ ) e podem ser introduzidas na célula, por vários tipos de metodologias, para o silenciamento de seu gene-alvo. Atualmente, várias empresas de biotecnologia oferecem moléculas de siRNA, para qualquer gene humano (ou camundongo) que o pesquisador pretenda silenciar. Uma característica importante é o tamanho da duplex que deve ter de 19 a 30 pares de base, uma vez que tamanhos maiores podem induzir respostas interferon inespecíficas em células animais.

Em cultura de células, a introdução de moléculas de siRNA é, em geral, feita através da formação de complexos dessas duplexes com polímeros químicos ou lipídeos, normalmente catiônicos. O complexo é endocitado pelas células e as duplexes de RNA são liberadas no citoplasma, sendo processadas pela maquinaria de RNA interferência, promovendo o silenciamento do gene-alvo. A utilização de siRNA tem sido largamente empregada em estudos de genômica funcional e em distintos testes clínicos em razão do silenciamento gênico específico e robusto induzido por essas moléculas. A fácil manipulação e a existência de sequências de siRNA para qualquer gene do genoma humano tornaram acessível o uso dessa ferramenta por diferentes grupos de pesquisa básica e aplicada. 


\section{Interferindo na expressão gênica in vivo}

A descoberta dos mecanismos de RNA interferência em células humanas é relativamente recente, mas, apesar disso, rapidamente verificou-se que o uso de RNAdf como ferramenta também pode ser feito in vivo, diretamente em animais. Obviamente, a maior parte desses testes pré-clínicos tem sido feita em camundongos, mas animais maiores, como macacos, também têm sido usados, e os resultados têm sido promissores. Isso estimulou o desenvolvimento de estudos diretamente em humanos, e vários protocolos clínicos já estão sendo testados. O potencial terapêutico de silenciamento através de RNA tem sido investigado tendo como alvo vários tipos de doenças, como câncer, doenças respiratórias, inflamação, doenças neurológicas, autoimunes e no combate a processos infecciosos (Figura 2). Alguns protocolos clínicos em fase I, que testam a segurança do uso de terapias em humanos, já foram concluídos e se verificou que moléculas de siRNA foram introduzidas em pessoas sem que se verificasse efeito tóxico. Mais do que isso, em vários casos identificou-se o funcionamento dessas duplexes no silenciamento do gene-alvo, como desejado.

O desenvolvimento de terapias baseadas em RNAi tornou-se um campo de pesquisa atrativo e promissor sobretudo nos casos em que a inibição de determinadas proteínas não teve sucesso pelos métodos farmacológicos tradicionais. Além disso, como o desenvolvimento de duplexes de RNA só depende do conhecimento da sequência do gene-alvo, o desenvolvimento dessas drogas é extremamente simples em relação ao tradicional drug design, no qual há necessidade de conhecimento da estrutura cristalográfica da proteína-alvo, o que não é garantia de sucesso em determinar os ligantes ativos nessas estruturas. Apesar de existirem casos nos quais as duplexes podem atuar em alvos diferentes do previsto (efeito conhecido como off-target), vários protocolos experimentais têm demonstrado a especificidade dada pela sequência dessas moléculas, o que estimula novas pesquisas na área.

Em geral, os trabalhos empregam as metodologias já bastante investigadas para introdução de DNA em organismos, em procedimentos de terapia gênica tradicional. Entretanto, algumas diferenças entre o uso dessas duas abordagens são claras e devem ser levadas em conta na escolha da metodologia. A molécula de siRNA é muito menor (entre 19 e 30 pares de bases), o que facilita sua entrega em relação aos vetores genéticos dependentes de DNA ou RNA (em geral alguns milhares de pares de base). Apesar disso, RNA é uma molécula muito mais instável, sendo degradada in vivo por RNAse. Essa característica exigiu diversos estudos em modificações químicas que aumentam sua estabilidade no organismo, sem prejudicar a ação dessas moléculas com fármacos.

Os testes com animais empregam siRNA ou shRNA através de várias vias de administração, o que depende do gene e do tecido-alvo. Por exemplo, aplicações intravenosas possibilitam que a duplex seja direcionada especialmente ao fígado, onde é interiorizado nas células. Por sua vez, introdução de siRNA 


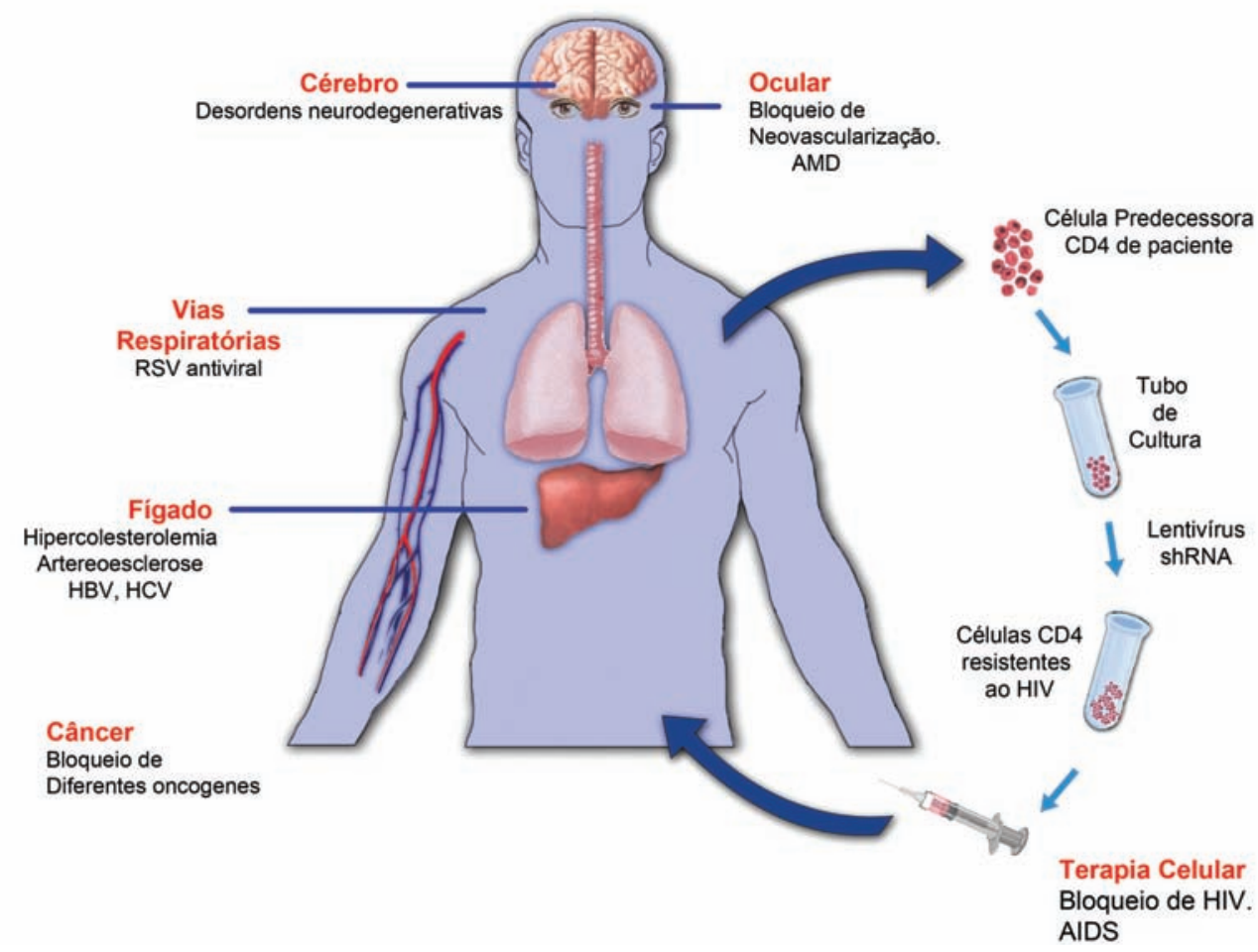

Figura 2 - Principais vias utilizadas para silenciamento gênico através de ação direta em protocolos humanos com RNA interferência.

por injeção intraocular garante um efeito direto nesse órgão, com a vantagem de o olho ser um compartimento de tamanho limitado, o que possibilita o uso de poucas moléculas, que ainda são efetivas no silenciamento gênico. Também tem tido muito sucesso o emprego de aplicação de duplexes de RNA através de inalação quando o alvo são as vias aéreas. Além disso, moléculas de siRNA têm sido aplicadas diretamente na pele, o que possibilita um alcance em vários pontos do organismo, ainda que preferencialmente em tecidos mais superficiais. Em geral, essas aplicações in vivo utilizam, como em cultura de células, complexos com polímeros ou lipídeos (poliplexos ou lipossomos) que constituem as nanopartículas que são endocitadas para interiorização das duplexes nas células. Curiosamente, no entanto, em várias aplicações, soluções salinas de siRNA são diretamente usadas e essas ainda são eficientes, promovendo o silenciamento do gene-alvo no organismo. Entretanto, é bastante provável que, em muitos desses casos, o uso das nanopartículas melhore a eficiência do fármaco. Nos casos de shRNA, em geral são empregados vetores genéticos derivados de vírus para sua expressão nas células. Como em outros procedimentos de terapia gênica, alguns dos casos são diretamente aplicados in vivo (por aplicação intravenosa, por exemplo), mas também há casos de aplicação ex vivo, que permite a modificação de células-tronco do próprio organismo com o vetor que expressa o shRNA (e promove o silenciamento do gene-alvo). Posteriormente, a célula modificada é reintroduzida no organismo, de modo a obter o benefício terapêutico. 


\section{Interferindo no genoma humano com fins terapêuticos}

Apesar de sabermos que o mecanismo de RNA interferência existe em células humanas há relativamente pouco tempo (desde 2001), é surpreendente como rapidamente foram iniciados protocolos clínicos em seres humanos empregando RNAi. Essa rapidez e relativo sucesso em alguns desses protocolos permitem prever que, em poucos anos, teremos essas moléculas sendo comercializadas em nossas farmácias e/ou aplicadas em nossos hospitais (Tiemann \& Rossi, 2009).

Entre as principais indicações de uso de RNA interferência, destacamse aquelas envolvidas em terapias oftalmológicas. Isso se deve basicamente à compartimentalização ocular, que permite a administração direta com injeções na cavidade vítrea. O compartimento ocular é livre de nucleases e moléculas de siRNA são internalizadas nas células-alvo. Essas vantagens têm sido exploradas por drogas terapêuticas que usam oligonucleotídeos, já comercializadas (Vitravene ${ }^{\circledR}$, Novartis e Macugen ${ }^{\circledR}$, Pfizer). Com duplexes de RNA (siRNA), os testes clínicos têm se concentrado no tratamento de doença macular relacionada à idade (AMD, do inglês age-related macular disease). O desenvolvimento de vascularização no fundo do olho, sobretudo em pessoas acima de sessenta anos de idade, prejudica a visão nesses pacientes com AMD, e o tratamento com siRNA visa silenciar a expressão de genes relacionados ao desenvolvimento de vasos, como o receptor de VEGF-I (VEGF - vascular endothelial growth factor). Testes clínicos de fase II/III, empregando 217 pacientes, indicaram uma melhora na acuidade visual em dois terços desses, demonstrando que essa tecnologia pode estar próxima de ser aprovada para comercialização. Entretanto, existem alguns problemas relacionados ao sistema de administração (injeção intraocular), e, curiosamente apesar dos resultados positivos, há polêmica quanto ao fato de parte dos efeitos se dever a respostas imunológicas não específicas, e não ao silenciamento específico pela siRNA (Hubschman et al., 2009). Estudos similares têm sido realizados empregando siRNA contra VEGF-A em pacientes diabéticos com edema macular.

Protocolos clínicos em fase II também estão sendo realizados para combater infecções respiratórias por vírus respiratório sincicial (RSV). Nesse caso, moléculas de siRNA contra genes virais são administradas através de inalação nos pacientes. Aparentemente os vírus RSV replicam células epiteliais superficiais do pulmão, que, por sua vez, são capazes de endocitar as duplexes de RNA, de modo que o silenciamento viral é eficiente. Testes clínicos com 88 indivíduos adultos sadios demonstraram que as moléculas de siRNA foram seguras e houve níveis significativamente menores de infecção em relação a indivíduos que receberam placebo (De Vincenzo et al., 2010).

O uso de RNA interferência como antiviral também está sendo testado clinicamente em terapia contra Aids. Nesses estudos, curiosamente, têm-se usado vetores virais derivados de HIV (agente etiológico da Aids) para expressão de shRNA em células-tronco de pacientes. Esses vetores, conhecidos como 
lentivírus, são capazes de se integrar permanentemente no genoma das células, as quais são então reimplantadas nos pacientes. Esse processo de transplante autólogo produz células (e principalmente linfócitos T4, alvo do vírus HIV) resistentes aos vírus, o que permite a recuperação do paciente. Dados têm sido promissores indicando que, mesmo dezoito meses após início da terapia, as células implantadas continuam a expressar o shRNA (Singh \& Gaur, 2009).

Além dos protocolos clínicos citados aqui, a tecnologia de RNA interferência ainda está sendo empregada em protocolos clínicos para outras doenças, como hepatite $\mathrm{B}$, diferentes tipos de tumores (incluindo melanoma), hipercolesterolemia, injúria renal aguda etc. Vários são os genes-alvo testados para combate o câncer: oncogenes, mediadores de ciclo celular e apoptose, genes envolvidos em degradação e estabilidade proteica, angiogênese, moléculas relacionadas à invasão metastática e adesão celular. Além disso, nossa proposta é o uso de siRNA como coadjuvantes nos tratamentos terapêuticos com radiação ionizante e agentes quimioterápicos. Para tanto, estamos testando o silenciamento de genes-alvo como aqueles que codificam proteínas antiapoptóticas, de multirresistência a drogas e mesmo envolvidas no reparo de DNA. Certamente, pelo número de testes pré-clínicos que estão sendo realizados, a lista de doenças-alvo a serem testadas diretamente em humanos, empregando diferentes estratégias de uso de RNA interferência, deverá ser bastante ampliada.

\section{A corrida do ouro}

\section{no desenvolvimento de novas terapias com RNAi}

A descoberta dos mecanismos de RNA interferência, apesar de recente, provocou uma verdadeira revolução na forma como é estudado o funcionamento dos genes nas células e também abriu perspectivas de intervenção direta na ação gênica in vivo. Em vários casos de doenças humanas, ocorre aumento de expressão de determinados genes, e o controle desses pelo silenciamento aparece como uma esperança na obtenção de novas formas de terapia. A obtenção de inibidores químicos continua sendo uma alternativa extremamente interessante em várias dessas doenças, porém o mecanismo de RNA interferência fornece uma abordagem simples (busca de complementaridade de sequência) para obter fármacos, ampliando seu potencial de uso e alcance. Esforços para uso dessa nova biotecnologia na clínica têm correspondido a um dos mais importantes exemplos recentes de medicina translacional, na qual o teste de laboratório é transferido rapidamente para o leito do paciente. Os desafios ainda são grandes, havendo necessidade de novas estratégias para maximizar a ação das moléculas efetoras dentro das células, assim como dos mecanismos de administração e entrega da molécula aos órgãos-alvo. Várias são as estratégias propostas, na teoria, para o direcionamento dessas moléculas de modo a garantir uma melhor especificidade no tecido-alvo, mas há necessidade de testes que possibilitem a demonstração de efetividade na prática.

Osdesafios, porém, não parecem assustar as grandes empresasfarmacológicas 
do mundo inteiro. Pequenas empresas montadas por pesquisadores estão sendo adquiridas por empresas multinacionais, que estão investindo bilhões em pesquisas de desenvolvimento, acreditando que as drogas e estratégias desenvolvidas com a abordagem de RNA interferência possam ter sucesso não só para doenças específicas, como também criem modelos para outras doenças. Esses investimentos têm sido tão flagrantes que parecem uma nova corrida do ouro no uso do conhecimento adquirido com décadas de estudo do genoma humano, na elaboração de novos fármacos. Entretanto, a aplicação de terapia baseada em RNA interferência deve ser analisada com cautela, visto que ainda requer intenso trabalho de pesquisa em todo o processo de elaboração de protocolos terapêuticos. O Brasil continua incipiente nesses estudos, de modo que apenas alguns grupos de pesquisa, nas universidades, têm o domínio da tecnologia para uso de RNA interferência. Um número ainda menor está envolvido diretamente no desenvolvimento de tecnologias novas empregando essa abordagem. Se esse verdadeiro silenciamento intelectual continuar na área, teremos que pagar caro pelas patentes e pelo uso dos novos medicamentos que muito provavelmente nos serão vendidos nas próximas décadas.

\section{Referências}

DE VINCENZO, J. et al. A randomized, double-blind, placebo-controlled study of an RNAi-based therapy directed against respiratory syncytial virus. Proc. Natl. Acad. Sci. USA, v.107, p.8800-5, 2010.

ELBASHIR, S. M. et al. Duplexes of 21-nucleotide RNAs mediate RNA interference in cultured mammalian cells. Nature, v.41, p.494-8, 2001.

FIRE, A. et al. Potent and specific genetic interference by double-stranded RNA in Caenorhabditis elegans. Nature, v.391, p.806-11, 1998.

HUBSCHMAN, J. P. et al. Age-related macular degeneration: experimental and emerging treatments. Clin. Ophthalmol., v.3, p.167-74, 2009.

LIU, J. Control of protein synthesis and mRNA degradation by microRNAs. Curr. Opin. Cell Biol., v.20, p.214-21, 2008.

SINGH, S. K.; GAUR, R. K. Progress towards therapeutic application of RNA interference for HIV infection. BioDrugs, v.23, p.269-76, 2009.

TIEMANN, K.; ROSSI, J. J. RNAi-based therapeutics-current status, challenges and prospects. EMBO Mol. Med., v.1, p.142-51, 2009.

RESUMO - A descoberta de que nossas células dispõem de um mecanismo de silenciamento gênico empregando RNA interferência ainda é muito recente. Apesar disso, em menos de uma década a investigação científica já alcançou progresso, suficiente para muito brevemente nos apropriarmos desse conhecimento com fins terapêuticos. Duplexes de RNA são potenciais fármacos e há investimentos altos nessa nova abordagem. Aparentemente, a promessa de terapia gênica parece finalmente atingir sua maturidade com essas novas ferramentas. 
PALAVRAS-CHAVE: RNA interferência, Silenciamento gênico, Câncer, Terapia gênica, Infecção viral.

ABSTRACT - The discovery of gene silencing mechanisms in our own cells using RNA interference is very recent. However, in less than a decade, the scientific investigation have progressed enough to make us see that, very soon, we will use this knowledge for therapeutic purposes. RNA duplexes are potential pharmaceutical drugs and there are high investments in this new strategy. The promising gene therapy seems to finally reach maturity with these new tools.

KEYWORDS: RNA interference, Gene silencing, Cancer, Gene therapy, Viral infection.

Carlos Frederico Martins Menck é professor do Departamento de Microbiologia do Instituto de Ciências Biomédicas (ICB) da Universidade de São Paulo.

@ - cfmmenck@usp.br

Recebido em 21.9.2010 e aceito em 27.9.2010. 